\title{
Communicating Through Music: An Analysis of Selected Songs from the Second Chimurenga
}

\author{
Professor Charles Pfukwa \\ Executive Dean, Faculty of Social Sciences \\ Bindura University of Science Education \\ Atherstone Road, Bindura, Zimbabwe \\ also \\ Research Fellow \\ Department of Linguistics and Modern Languages \\ University of South Africa \\ 1 Preller Street, Pretoria, 0003 \\ c4pfukwa@gmail.com
}

\section{ABSTRACT}

Every community has its own songs and performance styles that communicate, among other issues, its culture, ideology as well as its whims and fantasies. It can be used to communicate parts of all cultural activities and beliefs ranging from joy to the sombre tones of a funeral. Music becomes a social/ideological thread that holds a community together and facilitates all cultural activities in any community in the world. In this article, the writer discusses some effective ways in which music was effectively used to communicate and arouse positive feelings towards the Zimbabwean liberation struggle.

\section{The Zimbabwean Liberation War - The Second Chimurenga}

7 imbabwean anticolonial struggles have been given the umbrella term Chimurenga which is derived from a Zimbabwean patriarch Murenga Soro Renzou. This patriarch is a predecessor of Munhumutapa, Changamire and others (Beach, 1989). The first Chimurenga was the first war of resistance against the establishment of Rhodesia as a colony of the British empire, a group of European adventurers who called themselves pioneers.

The settlers took up large tracts of land for farming thereby displacing the local populace whose terms of land ownership were very different from the white settlers. This led to the first wars of resistance launched by Zimbabweans between 1893 and 1896. These wars are generally referred to as the first Chimurenga.

Black people were alienated from their land after the passing of the Land Apportionment Act of 1931, the Animal Husbandry Act of 1959 and the Land 
Tenure Act of 1969. The traumas that went along with these forced removals were never fully recorded and they gave the mistaken impression of consensus. The black population was beaten into submission. It is against this background that Zimbabweans took up arms against the Rhodesians. The first shots were fired at Chinhoyi in 1966 and the armed struggle against Rhodesians went on for another fourteen years and came to an end in 1979 (Ellert 1989; Bhebe 1999; Moorcraft and McLaughlin 1982).

\section{Significance of Chimurenga Songs}

Chimurenga songs communicated different themes such as the history of Zimbabwe, the purpose of the armed struggle, its conduct and efforts to link the people with their world. Songs were part of the ideological struggle. Some of these songs were so moving and were deeply embedded in the subconscious of both performer and audience. These songs also motivated the guerrillas to engage the enemy even when it meant sacrificing their lives. Some songs according to Pfukwa (2008), expressed resistance, defiance or were used to taunt the enemy.

Other songs were part of the recruitment drive to attract support from the people and to recruit new cadres (Pongweni, 1982). Others were sung during political orientation sessions as historical narratives in the typical traditional fashion of kuimba ngano (singing stories). In some cases, the songs were intended to communicate feelings that would ultimately motivate guerrillas to encounter traumatic experiences and to ease the burden of painful memories of the nightmares of the battlefield.

\section{The collective spirit}

In line with African tradition, Chimurenga songs were collectively composed and performed to encourage freedom fighters and villagers to collectively ensure that the obligations of the liberation struggle got collectively achieved. Such collectivity was one of the major objectives that guerrillas brought to the struggle from their communities. They used it as a powerful weapon against the enemy. The collective element communicated through music is also well researched by Vambe (2004).

Performance of a Chimurenga song was always collective, bursting with energy maybe except when singing the "anthem". There was no distinction between audience and performer. There was often a lot of dance, ululation, whistling and other paralinguistic elements to enrich the songs. Song and dance were an act of triumph over adversity. Chimurenga songs became narratives of the past, shared and experienced in the hunger, squalor, disease and death in camps and battlefields to communicate notions of bravery and self-sacrifice in the execution of liberation struggle.

This paper therefore argues that most Chimurenga songs can never be accredited to an individual. Western music separates performer or writer from the audience. Chimurenga songs did not have such boundaries. The audience and the 
performer fused, complementing each other as the performance unfolded. With each performance a song was recomposed, modified and enriched. This marked the power of collective composition and collective performance to communicate the desire to succeed, militarily, under difficult conditions.

\section{Song as historical narrative}

A song can be seen as a text that presents experiences that are sometimes difficult to narrate in other forms. In song, fact and fantasy can fuse to create some form of historical and cultural reality of a given people. In such situations, songs map out nodes of Zimbabwean history such as the second Chimurenga. Like any other war, the second Chimurenga it had its triumphs and tragedies, pain and passion which were communicated through song.

Javangwe, (2011) argues that all narratives are partial: they are always fragments of a bigger tapestry which can come as metaphor or symbols. The narration process in such situations become powerful representations of the past. War experiences are often traumatic and the songs are replete with bitter memories deeply imprinted in the mind (Mutambara 2014). Because of this, it is not easy to put together a coherent narrative, so song becomes a viable narrative form to communicate painful experiences.

\section{The songs}

The songs referred to in this article collected over several years. Some of them were taken from Pongweni (1982) and Pfukwa (2008). Others were taken from unstructured interviews with guerrillas and war collaborators who participated in the liberation struggle. For each song, a brief analysis of memories and histories is given. The selected songs discussed below illustrate the narrative force of the songs adopted to motivate people to support the liberation struggle. The songs are put in three categories to facilitate analysis and discussion. These are the "ngano/epic", the elegy and the song sung in motion.

\section{Some limitations of this collection}

Firstly, the songs are post-1975, yet the history of the Second Chimurenga goes back to the 1960s. After 1975, guerrilla numbers increased sharply in both Mozambique and Zambia (Tungamirai, 1996). Secondly, the songs were drawn from only one of the liberation armies, ZANLA. The other liberation army ZIPRA had an equally strong musical tradition which still needs to be documented. Thirdly, the songs are drawn from one Zimbabwean language, Shona. There are many Chimurenga songs in other Zimbabwean languages which still need to be recorded.

\section{The "nganolepic"}

Sendekera mukoma Takanyi is a long epic that was well documented by Pongweni (1982). A version of this song is also recorded on a website. This paper does not 
repeat the song but lifts excerpts of this long sonic narrative. In typical call and response style of traditional song, it narrated the whole Zimbabwean story, the history, the natural resources, the pain of colonial oppression, the suffering of the villagers who supported the war and many other horrors that Zimbabweans went through:

“...Vanamai vanonetswa nemabhunu vanobvunzwa vana varipiko..."
“...Our mothers are harassed by the boers as they are asked where are your children..."

It carried the inspiration and determination of the fighters in the struggle. In the same way that Mozambicans defeated the Portuguese, Zimbabweans were determined to defeat Ian Smith.

...Kaitano aimbovhaira baba
akarohwa nemaCamarada
Iye Simithi ari kuvhaira baba
arikurohwa ne makhomuredhi...
Caitano used to boast before he was defeated by the Camaradas

Smith is boasting, but he will be defeated by the Comrades...

In the same breath it sang about the treachery of Morris Nyati who led the Selous scouts to Nyadzonya camp in Mozambique and earned himself eternal infamy. The lines simply repeated the name:
...Pasi naNyati, Pasi naNyati
Pasi naNyati, kani amai
Pasi naNyati ...
Down with Nyati ...

The Nyadzonya massacre is one of those great tragedies of the liberation war where nearly one thousand refugees were killed and buried in mass graves.

Mukoma Takanyi never lost its freshness and emotional force because with each performance the song was perpetually recomposed, improved and modified. It did not need hours of practice but ability to infuse new elements, new ideas as the narrative built itself up. It was sung by the fireside in the evenings or at political gatherings.

Another epic which also narrated the Zimbabwean story was Maruza vapambepfumi (you have lost imperialists) which is also a call response song. It marks its start with the story of Chaminuka:

Kwanga kune mumwe murume

Zita rake Chaminuka

Aigara kuChitungwiza...
There was a certain man

His name was Chaminuka

He lived in Chitungwiza 
It also narrated the coming of the Europeans

...hevoka mapioneer...

Ndokudzikisa mureza wavo

wainzi yunyeni Jeki... ...then there were the Pioneers....

They raised their flag called the Union Jack...

The song goes on to narrate the colonial experience and the resolution to go to war. It is sharp, piquant, hurling deep insults at the colonial power.

...Mazigadzi aneunyope, Mazimhanza anokuya dovi!
Lazy wives,

Bald heads that grind peanut butter!

And, with tongue in cheek, it poked the Rhodesian enemy in eye

...tereraika munzwe, ZANU chiororo! ...listen, carefully,

ZANU is a bane!

This song was composed and performed by a choir with Chinx Chingaira as lead singer.

Chinx, supported by the Zanla Choir came to prominence with A message to the queen. This was a deliberate effort to sing in English but the music followed the call and response found in Mukoma Takanyi and Maruza Vapambepfumi. It also narrated the Zimbabwean struggle. Whereas the other songs were full of lamentation and suffering, the Message to the Queen was full of defiance. It was a song of triumph and was sung around the time of independence when Prince Charles came to officiate the Zimbabwean independence on 18 April 1980. So the song asked him to carry a message to the queen.

Maruza vapambepfumi was a song that was never really sung with the same ease as Mukoma Takanyi. The latter was composed in the pain and squalor of the refugee camps of Doroei and the training camps of Takawira and Tembue (Mutambara 2014). It was difficult to embellish and modify Maruza Vapambepfumi in the manner that every singer could recreate Mukoma Takanyi. The former was ultimately cast in stone when it was recorded after 1980. The origin of Mukoma Takanyi is difficult to trace. It probably was older than Nyadzonya, but it is not clear where it was created, whether in Zambia or in Mozambique. On the other hand, Maruza vapambepfumi was composed by the Zanla choir in Mozambique between 1978 and 1979 and went on to be recorded. So, while it was still collective, its collectivity was not as wide as that of Mukoma Takanyi. 


\section{Songs on the double - toi toi}

Pfukwa (2008) suggests the term toi toi originated in the camps of Mozambique and Tanzania. Zimbabweans might have borrowed it from troops in these respective countries. Pfukwa (op. cit.) also identifies some toi toi songs whose main features are discussed and explored below. They were short sharp dittys. They had the call and response to ensure rhythm in the march. Everyone was part of the song which had a lead voice and the rest responded in unison in voice and in step. Some were light hearted chants while others were deep insults. Toi toi was a collective experience often full of emotion and bursting with energy. It was a performance in motion and the performer was also the audience. Toi toi was a statement of the resilience and determination of a guerrilla force fighting against a well armed adversary. Rythm in motion was as important as meaning in song.

$\begin{array}{ll}\begin{array}{l}\text { Lead singer: Chiuya, chiuya } \\ \text { chiuyawo mukoma }\end{array} & \begin{array}{l}\text { Come, come } \\ \text { Come brother }\end{array} \\ \begin{array}{l}\text { chingers: Ramba wakadaro } \\ \text { Hehahe chiuya }\end{array} & \text { Keep on coming } \\ \begin{array}{l}\text { Rambawakadaro chiuya } \\ \text { Lead singer: Chiuya, chiuya }\end{array} & \text { Yes come } \\ & \text { Keep on coming } \\ \end{array}$

In the same breath, the lyrics could be quickly changed with rhythm in sync with the step:

Musana musana musana

Musana unodzimba maiwe

Zorodza musana

Zorodza musana

And still more change

Chiororo chiiko

He ha he

Chakasara kuZimbabwe

Changu chimwe chana

He ha he

Chakasara kuZimbabwe
The back (x3)

The back is painful

Rest the back

Rest the back

A string of these short ditties could be put together as long as the toi toi lasted, this could go up to an hour or more without anyone losing breath or getting exhausted. The striking thing is that toi toi was done by a force that was poorly equipped with half of it barefoot and there was never enough food. It is astonishing where these guerrillas, often malnourished, got the energy to bellow: 
Ndoichekacheka yebhunu!

Heyo!

Hondo iyo!

Heyo!

Hondo iyo!

Oye!

Oyiyerewo!

Hondo iyo!

Ndoicheka cheka ndouraya!

Heyo!

Hondo iyo!

Heyo!

Hondo iyo!

Oye!

Oyiyerewo!

Hondo iyo!
I will cut to pieces that of the Boer

Hey ho

The war!

Hey ho

The war
I will cut to pieces and kill

Hey ho

The war!

Hey ho

The war

(Pfukwa, 2008)

This toi toi song was a deep insult to the enemy and I cite Pfukwa (2008) here:

"It is full of innuendo and carries veiled obscenities...Cheka cheka means cutting to pieces and whatever it is, it belongs to the Boer. By adding $s$ to hondo, the word becomes shondo the Shona word for penis. The words then make sense: "I will cut up the penis of the Boer", which is a deep insult..."

Any guerrilla would delight in cutting up an adversary who wrought so much misery and death.

\section{An elegy}

To pay homage to the fallen the guerrillas sang 'Mwoyo Wangu'.

My heart

has pledged to die for Zimbabwe

My blood

will flow in the rivers

In the mountains

and in the rivers I shall sleep

eternally

To fulfil the task that was left to me.
Mwoyo wangu watsidza kufira Zimbabwe Ropa rangu nemunzizi richavavamo

Mumakomo, nemunzizi ticha ravamo

Kuzazisa basa randaka siirwa. 
The song was sung in a very solemn manner, with the right fist raised facing Zimbabwe. This song was a "last post" that was sung when a comrade died in camp and on important occasions. Ideally, it would have been sung even in the front but circumstances often did not permit decent burial let alone any kind of internment. It goes without saying as casualties rose the song became frequent but it never lost the solemn note.

\section{Conclusion}

This paper has given a brief overview of the power of the narrative communication used to communicate notions and feelings of the liberation fighters. The songs reflect and illuminate the pain, the losses, the squalor and all the other hardships of Chimurenga.

\section{References}

Beach, D. 1989. Mapondera 1840-1904. Gweru: Mambo Press.

Bhebe, N. 1999. The Zapu and Zanu Guerrilla Warfare and the Evangelical Lutheran Church. Gweru: Mambo Press.

Ellert, H. 1989. The Rhodesian Front War, Counter-Insurgency Guerrilla war:

Javangwe, T. D. 2011. Contesting Narratives: Constructions of Self and Nation in Zimbabwe's Political Autobiography. Unpublished PhD Thesis, Department of English Studies, UNISA.

Moorcraft, P. L. and McLaughlin, P. 1982. Chimurenga: The war in Rhodesia 19651980. Marshaltown: Sigma/Collins.

Mutambara, A. 2014. The Rebel in me Pinetown (SA) : $30^{\circ}$ South Publishers with Helion and Co.

Ntshinga T. 2009. Song texts and ambiguities of oral performance Muziki Vol. 6 No 1, 36-48:

Pfukwa, C. 2008. Black September et al. Chimurenga songs as historical narratives in the Zimbabwean Liberation war, Muziki: 5:1, 30-61 UNISA.

Pongweni, A.J.C. 1982 Songs won the liberation war. Harare: College Press.

Smith. S. And Watson, J. 2001. Reading Autobiography: a guide for interpreting life narratives. Minneapolis, University of Minnesota Press.

Tungamirai, J. 1995. Recruitment to ZANLA: Building up a War Machine. In Bhebhe, N. and Ranger, T. eds. Soldiers in Zimbabwe's Liberation War. Harare: UZ Publications. 36-47.

Vambe, M.T. 2004 Orality in the Zimbabwean Novel in English, Pretoria, UNISA Press.

Zegeye, A. and Vambe, M 2009. Close to the sources. Pretoria: UNISA Press 1962-1980. Gweru: Mambo Press. 